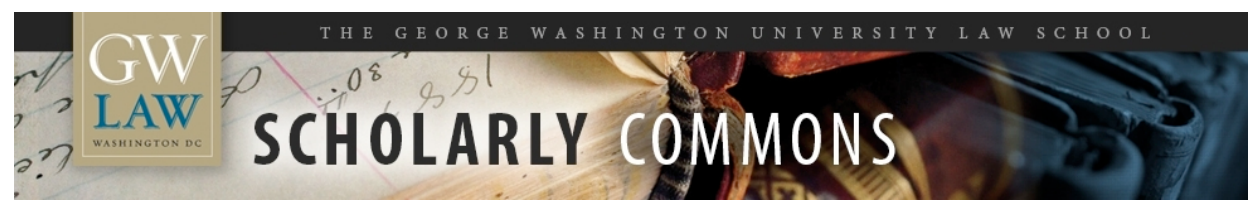

GW Law Faculty Publications \& Other Works

Faculty Scholarship

2021

Foster Care and the Growing Tension Between the Religion

Clauses: A Comment on Rogers v. HHS

Robert W. Tuttle

Follow this and additional works at: https://scholarship.law.gwu.edu/faculty_publications

Part of the Law Commons 


\title{
Foster Care and the Growing Tension Between the Religion Clauses: A Comment on Rogers v. HHS
}

\author{
Robert W. Tuttle ${ }^{1}$
}

\section{Introduction}

Rogers v United States Department of Health and Human Services, ${ }^{2}$ pending now in federal district court in South Carolina, provides an ideal vehicle to study the interaction between the Establishment Clause and the Free Exercise Clause of the First Amendment. At first glance, the facts in Rogers resemble those in Fulton v. City of Philadelphia, ${ }^{3}$ decided by the Supreme Court this summer. Both cases involve non-discrimination rules that control a faithbased Child Placement Agency's (CPA) participation in the government-controlled fields of foster family certification and child placement. Those rules include a prohibition on discrimination based on race, religion, sex, and sexual orientation, among other grounds. But any similarity between Fulton and Rogers ends at the surface. In Fulton, the City of Philadelphia refused to contract with Catholic Social Services for services as a CPA because CSS would not certify same-sex couples as foster parents. Rogers involves explicit religious discrimination by South Carolina's largest CPA, Miracle Hill, which certifies as foster parents only those who conform to the Agency's evangelical Protestant beliefs and practices. The state and federal governments granted Miracle Hill waivers of non-discrimination rules that would have barred its operation as a CPA.

In Rogers, the plaintiffs are a same sex married couple, Unitarian in their faith. They allege that the federal and state governments violated the Establishment and Equal Protection Clauses by delegating control over the selection of foster parents to an entity the government knew would discriminate based on religion and sexual orientation. ${ }^{4}$ In Fulton, by contrast, the CPA was the party raising constitutional claims. CSS argued that Philadelphia violated its rights under the Free Exercise Clause by refusing to contract with the agency. In an opinion characterized by very thin reasoning, the Supreme Court ruled in favor of CSS. The Court's decision, however, tells us nothing about the limits that the Establishment Clause might impose on "accommodations of religion," including exemptions of faith-motivated practices from general laws. A close comparison of these two cases can tell us much about the current, very unsettled state of Religion Clause law, as it applies to foster care and the full range of government funded services provided by faith-based organizations.

\footnotetext{
${ }^{1}$ David R. and Sherry Kirschner Berz Research Professor of Law and Religion, George Washington University Law School. Special thanks to Chip Lupu for his immense help with this paper, and also to Naomi Cahn, Micah Schwartzman, and Greg Strauss for inviting me to be part of this symposium. This article is forthcoming in volume 60 of the Family Court Review (2022).

2 Rogers v. United States HHS, 466 F. Supp. 3d 625 (D.S.C. 2020).

${ }^{3}$ Fulton v. City of Philadelphia, 141 S. Ct. 1868 (2021).

${ }^{4}$ In Maddonna v. U.S. Dept of Health \& Human SvCS. (D. S.C., 6:19-cv-3551-TMC, August 10, 2020), the state and federal defendants in Rogers face another challenge over their role in Miracle Hill's refusal to provide foster care services to a Roman Catholic family. As in Rogers, the court denied defendants' motion to dismiss, and the state defendants' motion to dismiss in light of Fulton is under consideration. The Religion Clause analysis that I offer in this paper applies equally to Maddonna and the cases should reach the same outcome.
} 
Part 1 of the paper describes the two cases in more detail. It begins with Rogers v. HHS, currently in discovery after an unsuccessful motion by the government defendants to dismiss, although the state defendants have recently filed a new motion to dismiss in light of Fulton. Part 1 then offers a brief overview of the Supreme Court's decision in Fulton. The opinions raise important issues, ${ }^{5}$ but this paper focuses only on the approach used by the Opinion of the Court to resolve the dispute.

Part 2 of the paper starts with the state defendants' new motion to dismiss. They argue that the Court's decision in Fulton compels the government to accommodate Miracle Hill's free exercise right to select foster parents based on the agency's religious commitments. The district court should dismiss that motion. Miracle Hill's free exercise rights are not part of this litigation; indeed, the CPA is not even a party. More importantly, the state defendants ignore the difference between discrimination based on sexual orientation and discrimination based on religion. Though both protected categories have constitutional grounding, the roots of a prohibition on religious discrimination by the state run much deeper.

Part 2 continues with discussion of alternative grounds that the plaintiffs could use to prevail in Rogers, and on which courts can rely if CPAs make free exercise challenges to a ban on religion-based discrimination by such agencies. In section $2 \mathrm{~B}$, I offer an approach to establishment clause analysis that elaborates on and clarifies the one adopted by the Rogers court in its denial of the motion to dismiss. This approach focuses on the relationships among the state, the CPA, prospective foster parents, and foster children. Identifying the "beneficiary" in the state's grant or contract with the CPA is the key to this analysis. By examining these relationships, we can highlight the most fundamental concerns of non-establishment. These include the dangers of delegation of government powers to a preferred religious entity; the exclusion of non-adherents from a government program made available to members of one or more faiths; and, perhaps most controversially, state responsibility for religious indoctrination of children.

Section $2 \mathrm{C}$ explores the possibility of a free exercise claim by Miracle Hill in the likely event that the Biden Administration revokes the waiver, granted to Miracle Hill by the Trump Administration, of HHS non-discrimination policies. ${ }^{6}$ Based on Fulton, Miracle Hill's claim would be assessed under a standard of strict scrutiny because the federal regulations permit HHS to

\footnotetext{
${ }^{5}$ Chip Lupu and I have addressed some of these issues, including Justice Alito's dubious arguments for reversing the Court's decision in Employment Div., Dept. of Human Resources of Ore. v. Smith, 494 U.S. 872 (1990). See Ira C. Lupu and Robert W. Tuttle, The Radical Uncertainty of Free Exercise Principles: A Comment on Fulton v. City of Phila, Amer. Const. Soc. Sup. CT. Rev. (5 $5^{\text {TH }}$ ED. 2020-2021) (Forthcoming). Available online at: https://papers.ssrn.com/sol3/papers.cfm?abstract_id=3888375.

${ }^{6}$ The state defendants' renewed motion to dismiss under F.R.C.P 12(c) raises this hypothetical question. But because Miracle Hill has not sued, the legal issue remains hypothetical and not ripe for adjudication. Rogers v. United States HHS, Civil Action No. 6:19-cv-01567-JD, Defendants Henry McMaster's and Michael Leach's Motion for Judgment on the Pleadings (hereafter "State Defendants 12(c) motion") (July 15, 2021). The Federal defendants did not seek similar relief, strongly suggesting that the Biden Administration will withdraw its waiver or even change the HHS rules permitting waiver of some non-discrimination provisions.
} 
waive its non-discrimination policy in some contexts. ${ }^{7}$ Unlike the case for CSS in Fulton, however, Miracle Hill's free exercise claim should fail. Although the CPA may be able to demonstrate that its sincerely held beliefs have been substantially burdened by denial of a waiver, the government should prevail in the Rogers context by showing that it has a compelling interest in denying an exemption for religion-based discrimination and has no less restrictive means of achieving that interest.

\section{The Cases}

Rogers and Fulton share important features. Both involve "Culture Wars" clashes between traditionalist religious institutions and same-sex families. Unlike Masterpiece Cakeshop ${ }^{8}$ or Arlene's Flowers, ${ }^{9}$ in which a private entity discriminated against a same-sex couple, these cases place the government at the center of the dispute. Foster care is controlled by the state because the children in need of placement are wards of the state. The discrimination - or asserted right to discriminate-occurs in a world dominated by the state, even if responsibilities are contracted out to private entities.

\section{A. Rogers v. United States Department of Health and Human Services ("HHS")}

Miracle Hill, a provider deeply committed to Evangelical Protestant Christianity, is the largest CPA in South Carolina. It is the dominant provider of foster care placement services in most upstate counties. ${ }^{10}$ In 2018, however, South Carolina officials discovered that Miracle Hill, which had provided services for many years, does not comply with state and federal nondiscrimination requirements. ${ }^{11}$ Specifically, Miracle Hill certifies as foster parents only those who are Evangelical Protestants. That limitation, based on Miracle Hill's understanding of its faith, obviously excludes members of other faiths and also excludes same-sex couples. ${ }^{12}$

Faced with the revocation of Miracle Hill's qualification as a licensed provider, South Carolina Governor McMaster ordered the state Department of Social Service to waive Miracle Hill's obligation to comply with the state non-discrimination rules and asked HHS to waive the federal non-discrimination rules. ${ }^{13}$ HHS granted McMaster's request for a waiver of federal rules, and the state promptly renewed Miracle Hill's license to serve as a CPA. ${ }^{14}$

\footnotetext{
${ }^{7}$ Fulton, 141 S. Ct. at 1877.

${ }^{8}$ Masterpiece Cakeshop v. Colorado Civil Rights Comm'n, 584 U.S. (2018); 138 S. Ct. 1719.

${ }^{9}$ State of Washington v. Arlene's Flowers, 441 P.3d 1203 (Wash. 2019) (on remand from the U.S. Supreme Court).

${ }^{10}$ Rogers, 466 F. Supp. 3d 625, 635.

${ }^{11} \mathrm{Id}$. at 634-635 (citing relevant regulations that prohibit certain forms of discrimination in foster care).

12 Id. at 635-636.

13 Id. at 636.

${ }^{14}$ South Carolina is far from alone in granting CPAs the right to discriminate on the basis of religion in providing foster care services. See https://everychilddeservesafamily.com/state-bills (last visited September 30, 2021) (9 states have statutes that specifically permit religious CPAs to discriminate, in addition to South Carolina's administrative waiver at issue in Rogers). See generally, Adrianne M. Spoto, Note: Fostering Discrimination: Religious Exemption Laws in Child Welfare and the LGBTQ Community, 96 N.Y.U. L. Rev. 296 (2021); Jordan Blair Woods, Religious Exemptions and LGBTQ Child Welfare, 103 Minn. L. Rev. 2343 (2019); Tracy Smith, Note \&
} 
Plaintiffs Eden Rogers and Carolyn Welch, a same-sex couple who belong to a UnitarianUniversalist church, applied to Miracle Hill as prospective foster parents. The agency rejected their application because the couple does not share its religious beliefs, including both theological understandings and a commitment to exclusively heterosexual marriage. ${ }^{15}$ The plaintiffs filed suit against the government actors who enabled the relationship between the state and Miracle Hill. The suit alleges that, by granting a license ${ }^{16}$ to Miracle Hill, those actors violated plaintiffs' rights to equal protection based on religion and sexual orientation, and violated the Establishment Clause. ${ }^{17}$ Although the Equal Protection claims are important and deserve close attention, this paper only explores the alleged Establishment Clause violation.

The government defendants filed a motion to dismiss plaintiffs' claims under the Establishment and Equal Protection Clauses. The federal district court for the District of South Carolina, in an opinion by Judge Timothy Cain, denied the motion to dismiss. ${ }^{18}$ With respect to the alleged violation of the Establishment Clause, Judge Cain used the familiar but oft-criticized criteria from Lemon v. Kurtzman ${ }^{19}$ to analyze the relevant allegations. He focused on the second criterion - that the challenged government action may not have a "principal effect" that favors "a particular religious view or religion in general." 20 Judge Cain then invoked the "endorsement test" to explicate the second prong of Lemon. Under that test, the government's action would be deemed to have an impermissible primary effect if "a reasonable, informed observer would understand that the practice under review in fact conveys a message of endorsement or disapproval of a religion." 21

Using these standards, Judge Cain held that the plaintiffs' claims survived the motion to dismiss. The actions of state and federal defendants, Judge Cain reasoned, could demonstrate endorsement of the religious views of Miracle Hill. ${ }^{22}$ By permitting Miracle Hill to reject all prospective foster parents except those who share its faith, the government could be complicit

Comment: Stretching the First Amendment: Religious Freedom and Its Constitutional Limits within the Adoption Sector, 46 Pepp. L. Rev. 113 (2018); Allison L. McQueen, Note: Michigan's Exemption for Faith-Based Adoption Agencies: State-Sanctioned Discrimination or Guardian of Religious Liberty?, 93 Notre Dame L. Rev. 895 (2017). ${ }^{15}$ Rogers, 466 F. Supp. 3d. at 636-637.

${ }^{16} \mathrm{~A}$ license to provide foster-care related activities gives the license holder access to federal and state funding for its work - but more importantly, the CPA holds the delegated power of the state to identify eligible foster parents and (although not at issue in this case) make recommendations for the placement of children in those homes and monitor the children's welfare while in that placement. See S.C. Code Ann.§ 63-9-30(5) (defining a "child placing agency").

${ }^{17}$ Rogers, 466 F. Supp. 3d. at 637.

${ }^{18} \mathrm{Id}$. at 646-647. The court dismissed plaintiffs' equal protection claim based on religious discrimination, concluding that the state would permit any faith-based CPA to prefer co-religionists in certifying prospective foster parents. Id. at 650-652.

${ }^{19} 403$ U.S. 602 (1971). Rogers, 466 F. Supp. 3d. at 646.

${ }^{20}$ Rogers, 466 F. Supp. 3d. at 647 (quoting Wood v. Arnold, 915 F.3d 308, 316 (4 $4^{\text {th }}$ Cir. 2019)).

${ }^{21}$ Rogers at 647-648 (quoting Wood, 915 F.3d at 316). For Justice O'Connor's classic exposition of the endorsement theory, see Lynch v. Donnelly, 465 U.S. 668, 688-694 (1983) (O'Connor, J., concurring).

${ }^{22}$ Rogers, 466 F. Supp. 3d. at 646-648 
in steering those parents toward the religious beliefs of Miracle Hill. ${ }^{23}$ Miracle Hill's large caseload, as compared with all others combined in these counties, would aggravate that complicity. ${ }^{24}$

The court did not conclude that the government had violated the Establishment Clause or enjoin the state license to Miracle Hill. But Judge Cain permitted plaintiffs to proceed to discovery on their Establishment Clause claim.

\section{B. Fulton v. City of Philadelphia}

For many years, Catholic Social Services of Philadelphia (CSS) contracted with the City to provide a variety of services as a CPA. Among those services was assessment of prospective foster parents. ${ }^{25}$ Both the City's policy on social welfare contracting and its public accommodations law prohibit discrimination based on sexual orientation. ${ }^{26}$ After news media reported that CSS refused to certify same-sex couples as foster parents, the City refused to renew its contract with CSS for foster family assessments. ${ }^{27}$

CSS filed suit, claiming that the City's denial of a new contract was the product of animosity toward Catholicism and its traditional view of marriage. ${ }^{28}$ Both the district court and the U.S. Court of Appeals rejected all of CSS's constitutional arguments. ${ }^{29}$ The Supreme Court granted certiorari on two questions: whether the City impermissibly excluded CSS from its foster care program, and whether Employment Div. v. Smith should remain controlling law for assessing incidental burdens on religiously motivated conduct. ${ }^{30}$

In a unanimous decision, the Court ruled for CSS. The basis for that decision, however, is far from unanimous. Justices Alito, Thomas and Gorsuch would have overruled Employment Div. $v$ Smith. In their view, courts should apply strict scrutiny to any government imposition of a substantial burden on religiously motivated conduct, even if the law is "neutral and generally applicable." ${ }^{31}$ The other six justices declined to reach the question of Smith's continuing viability. Instead, they concluded, on highly questionable grounds, ${ }^{32}$ that the City's nondiscrimination rules were subject to waiver and thus not "generally applicable." 33

\footnotetext{
${ }^{23}$ Id. at 648 (quoting Santa Fe Indep. Sch. Dist. v. Doe, 530 U.S. 290, 302 (2000)).

${ }^{24}$ The court also drew on a line of decisions that prohibits the government from delegating certain discretionary public functions to religious organizations. Id. at 648 (citing Board of Educ. of Kiryas Joel Village Sch. Dist. v. Grumet, 512 U.S. 687 (1994); Larkin v. Grendel's Den, Inc., 459 U.S. 116 (1982)). I return to this line of argument in Part 2B.

${ }^{25}$ Fulton v. City of Philadelphia, 141 S. Ct. 1868, 1875.

${ }^{26}$ Id. at $1875-1876$.

${ }^{27}$ Id. at 1875 .

${ }^{28}$ Id. at 1876.

${ }^{29} \mathrm{ld}$.

${ }^{30} \mathrm{Id}$. at $1876-1877$.

${ }^{31}$ Id. at 1883-1889 (Alito, J., concurring in the judgement).

${ }^{32}$ See Lupu \& Tuttle, Radical Uncertainty, supra note XX, at ___ (SSRN text at 7)

${ }^{33}$ Fulton, 141 S. Ct. at 1877.
} 
Based on that finding, the Court applied strict scrutiny to analyze Philadelphia's reasons to refusing to contract with CSS. It criticized the City for asserting reasons at "a high level of generality," rather than the specificity required to show a compelling government interest for denying the requested accommodation. ${ }^{34}$ Importantly, the Court did not treat CSS's discrimination based on sexual orientation as a sufficiently compelling reason to justify denial of a contract with the CPA. ${ }^{35}$ The Court relied on the availability in Philadelphia of other child welfare agencies to place children with same sex couples, as well as the waiver power itself as a sign that the interest in non-discrimination might be overcome by other considerations.

Justice Alito's sprawling 78-page opinion, arguing that the Court should abandon Smith, attracted much interest and speculation about its potential status as a failed majority opinion. ${ }^{36}$ The real impact of Fulton, however, resides in the Court's surprising, quiet, and potentially vast expansion of the scope of rules that lack "general applicability" and are thus subject to more searching judicial review. Philadelphia had never granted an exception to its non-discrimination rules. ${ }^{37}$ Nevertheless, the Court held the grant of authority to grant exemptions deprives the challenged rule of general applicability; if a religious exemption is denied, the disappointed claimant enjoys the benefit of strict scrutiny for its Free Exercise challenge.

\section{Rogers and Fulton - the interplay of Free Exercise and Establishment Clause norms}

The Court's decision in Fulton will certainly affect relationships between governments and faith-based CPAs. But the presence of religion-based discrimination in Rogers invites consideration of broad questions, not present in Fulton, about the interaction of the Free Exercise and Establishment Clauses.

\section{A. The renewed motion to dismiss in Rogers.}

Less than a month after the Supreme Court's decision in Fulton, the state defendants in Rogers asked the court to reconsider their motion to dismiss. ${ }^{38}$ The state defendants argue that the Supreme Court's decision in Fulton requires the district court to grant the motion to dismiss. On their proffered interpretation of Fulton, the state defendants are compelled by the Free Exercise Clause to grant Miracle Hill an exemption, and to continue to work with the CPA notwithstanding its refusal to certify same-sex couples, or non-evangelical Protestant couples, as eligible foster parents. ${ }^{39}$

\footnotetext{
${ }^{34}$ Id. at $1881-82$.

35 Id. at 1882.

${ }^{36}$ Lupu \& Tuttle, Radical Uncertainty, supra note XX, at ___ (SSRN text at 6-7).

37 The City argued that the power to grant exceptions did not even apply to the process of assessing prospective foster parents, but the Court rejected this argument. Fulton, $141 \mathrm{~S}$. Ct. at 1878-1879.

${ }^{38}$ State Defendants 12 (c) motion.

${ }^{39}$ State Defendants 12 (c) motion, at 13-22.
} 
Even if the administrative waiver provisions in state and federal rules mean that those schemes are, in light of Fulton, not "generally applicable," the direct parallel between Rogers and Fulton is strained, particularly at this stage of the litigation. In their opposition brief, the Rogers plaintiffs make two arguments against the state defendants' renewed motion to dismiss. First, they contend that the state defendants stand in the awkward position of raising a hypothetical free exercise challenge to an action they have not taken - that is, the refusal to contract with Miracle Hill because of its religion-based discrimination. Because Miracle Hill is not a party before the Court and the pleadings have focused on defendants' violations of the Establishment Clause, plaintiffs argue, the court should not adjudicate potential free exercise rights of CPAs that might be required to comply with non-discrimination rules in the future. ${ }^{40}$ Later in this section, I discuss the merits of this argument, because it raises important questions about future developments in the litigation.

Plaintiffs also point to significant differences between the facts of Fulton and those alleged in Rogers. In Fulton, same-sex couples had multiple alternative options for certification as foster parents, and no couple claimed that they had been turned away by CSS. In Rogers, however, plaintiffs alleged that South Carolina lacks adequate alternative providers comparable to Miracle Hill, and that they had been rejected as potential foster parents by Miracle Hill. ${ }^{41}$ To decide the case, the court would certainly need to know whether South Carolina provided potential foster parents of other faiths (and all same-sex couples) reasonable alternative opportunities to be certified as eligible foster parents. This argument should provide the court with ample reason to dismiss the state defendants' motion. Whether Fulton ultimately controls the disposition of this case will likely require a determination of facts and cannot be decided on a motion to dismiss.

The first of the state defendants' grounds, however, implicates the complex relationship between the Free Exercise and Establishment Clauses. The state defendants essentially argue that a mandatory Free Exercise accommodation for Miracle Hill would override or negate what might otherwise be an Establishment Clause violation. On this reasoning, if Fulton requires the accommodation, the state defendants must prevail as a matter of law. ${ }^{42}$ But the argument is profoundly flawed. Some accommodations of religion do violate the Establishment Clause. To call an exemption an "accommodation" does not make it immune to constitutional review, so the court must determine whether the state's arrangement with Miracle Hill is such a violation. ${ }^{43}$ Because the Establishment Clause, unlike the Free Exercise Clause, is not subject to

\footnotetext{
${ }^{40}$ Rogers v. United States HHS, Civil Action No. 6:19-cv-01567-JD, Plaintiffs' Opposition to Defendants Henry McMaster's and Michael Leach's Motion for Judgment on the Pleadings (hereafter "Plaintiffs' Opposition brief") (August 12, 2021), at 7-11. The court makes the same argument in its denial of defendants' motion to dismiss. Rogers, 466 F. Supp. 3d at 649 n.7.

${ }^{41}$ Plaintiffs' Opposition brief, at 16-17

42 This assertion that Free Exercise trumps non-Establishment is an inversion of state attempts, recently quite unsuccessful, to rely on the Establishment Clause or similar state constitutional provisions to deny plaintiffs' claims under the Free Exercise or Speech Clauses. These cases have been more frequent in recent years. See, e.g., Trinity Lutheran Church v. Comer, 582 US _, 137 S. Ct. 2012 (2017).

${ }^{43}$ See, e.g., Kiryas Joel, 512 U.S. 687 (1994); Estate of Thornton v. Caldor, 472 U.S. 703 (1985),
} 
interest balancing, a determination that state action violates the Establishment Clause should end the case, notwithstanding Free Exercise interests of those who seek an accommodation.

Notably, the federal defendants did not file a parallel 12(c) motion for reconsideration after Fulton. Perhaps they declined because they saw that Establishment Clause considerations dictate a different outcome in Rogers. In any event, the federal government seems likely, at some point, to revoke the waiver the Trump administration HHS granted to Miracle Hill. If that happens, the hypothetical Free Exercise question in the state defendants' motion would become concrete, and Miracle Hill would either move to intervene in this case or file a separate suit against the federal government. The remainder of this paper reassesses the court's application of the Establishment Clause in Rogers and considers the full range of the federal government's potential defenses in such a suit.

\section{B. Reframing the court's Establishment Clause analysis in Rogers.}

When the district court denied the state's initial motion to dismiss, as it should do with the renewed motion to dismiss, the court relied on well-worn concepts in Establishment Clause law. It started with the Lemon test, and then incorporated the "endorsement" standard to interpret the second prong of the Lemon test. ${ }^{44}$ This approach seems less than promising. The Supreme Court has not found a violation of the Establishment Clause since 2005, ${ }^{45}$ and its more recent decisions have minimized the importance of both the Lemon test and the concept of endorsement. Advocates need a new and more nuanced approach to the Establishment Clause to inject some vitality into the relevant law.

As Chip Lupu and I have argued elsewhere, a better approach assesses the extent of the state actor's responsibility for religious indoctrination. ${ }^{46}$ This removes the focus from the evershifting identity and uncertain perceptions of the "reasonable observer" under the endorsement standard. ${ }^{47}$ It also directs attention to practices more central to the Establishment Clause - the state's involvement with worship and religious education. In important respects, our approach brings to normative life the idea behind the first two prongs of the Lemon standard. At the most basic level, the state is responsible when it acts with the specific intent of promoting religious observance or education. ${ }^{48}$ But specific intent does not exhaust the scope of an actor's responsibility. As with private actors under ordinary principles

\footnotetext{
${ }^{44}$ See infra text at notes $X X-X X$.

${ }^{45}$ McCreary County v. American Civil Liberties Union, 543 U.S. 844 (2005) (County's courthouse display of a plaque containing the Ten Commandments violated the Establishment Clause).

${ }^{46}$ Ira C. Lupu and Robert W. Tuttle, SeCular Government, Religious PeOPLE 88 (2014) ("The state may not act as a locus of worship, assert its own religious competence, nor commission private communities of worship to act as the state's agent for the creation, maintenance, or transformation of religious identities").

${ }^{47}$ See, e.g., County of Allegheny v. ACLU, 492 U.S. 573, 668-674 (Kennedy, J., concurring in the judgment and dissenting in part) (lengthy critique of the "endorsement standard").

${ }^{48}$ See McCreary County, 543 U.S. at 859-866; Wallace v Jaffree, 472 U.S. 38, 56-80 (1985).
} 
of civil or criminal law, responsibility includes actions that that will foreseeably and inevitably create a certain outcome, unless the actor takes steps to avoid or minimize that outcome. ${ }^{49}$

Thus, when the state acts in ways that inevitably promote worship or religious indoctrination, and takes no steps to mitigate that effect, its actions violate the Establishment Clause. ${ }^{50}$ This conclusion is even more appropriate when the result foreseeably materially benefits a particular faith. Virtually all modern Establishment Clause jurisprudence is designed around this principle, though it is rarely made explicit and this way of articulating it is likely to sound quite alien to those in the field. When the state takes action that benefits religion, the relevant constitutional inquiry is whether its conduct was intended to benefit a particular faith, and whether it should be held responsible for any religion-advancing benefit that accrues to a particular faith community. ${ }^{51}$ In the law of government funding of private schools, for example, "independent private choice" places responsibility for religious education on a student's parent or guardian, who is presumed to have had an adequate choice among secular and religious schools. ${ }^{52}$

Along the same lines, in the law of direct public funding by religious organizations, two features insulate the government from responsibility for promoting religious education. First, the program must have a neutral class of eligible recipients. Second, the funds must be used to purchase secular goods or services. ${ }^{53}$ These requirements, taken together, absolve the state of responsibility for religious indoctrination by the grantees.

Similarly, in challenges to public displays of religious symbols, the Court has emphasized that the symbol also carries an independent secular meaning that is properly attributable to the state. Any symbolism that would ally the state with a religious message is apparently overcome by the permissible secular message. ${ }^{54}$ The logic in these decisions is severely strained, but the move itself is explicable only by the Court's effort to absolve the state of responsibility for promoting a religious message.

\footnotetext{
${ }^{49}$ Restatement (Second) of Torts, $§ 284$ (negligent conduct defined); §313 (liability for unintended but foreseeable emotional distress); §877(b) (liability of person permitting act of another). Model Penal Code, §2.02 (General Requirements of Culpability); §2.03 (Causal Relationship Between Conduct and Result).

50 School Dist. of Abington Township v. Schempp, 374 U.S. 203, 222-225 (1963).

51 Id. at 222-223.

52 Zelman v. Simmons Harris, 536 U.S. 639, 649-654; see also id. at 670-676 (O'Connor, J., concurring).

53 Trinity Lutheran Church v. Comer, 137 S. Ct. 2012, 2023 (2017) (the Court assumes that the playground will be used for secular purposes and specifically does not decide how the Free Exercise and Establishment Clauses would interact if the funding included direct support for a house of worship or other religious facility. See id. at 2024 n.3). See also Mitchell v. Helms, 530 U.S. 793, 820-825 (Thomas, J., plurality opinion) (government aid to religious organization must be secular in content). See also id. at 861-863 (O'Connor, J., concurring in the judgment) (challenged program had adequate safeguards to prevent government-provided secular materials from being used for religious activities).

${ }^{54}$ Am. Legion v. Am. Humanists Ass'n, 139 S. Ct. 2067, 2084-85 (2019); See also Town of Greece v. Galloway, 575

U.S. 565, 582-583 (2014).
} 
For Establishment Clause analysis, attribution of such responsibility in foster care services presents more subtle questions than in these other contexts. If a jurisdiction has a wide diversity of CPAs and those CPAs certify and place children in homes without regard to the religion of the foster parents, then the government does not bear responsibility for foster children's religious experience in the placements. If, however, the jurisdiction's placements are predominantly limited to foster parents of a particular faith, the government would be responsible the children's religious indoctrination. This concern would only be enhanced if the CPA monitors the children's religious education in addition to other aspects of their welfare.

When a CPA selects only co-religionists for the role of foster parents, it might be tempting to analogize prospective foster parents to prospective employees of a religious organization. Under Title VII, religious organizations are exempt from the prohibition on religious discrimination in employment. ${ }^{55}$ Houses of worship and other faith-based entities may hire those who fully share the mission of the organization and can be relied on to deliver services in a manner consistent with that mission. Miracle Hill seems to invoke that general idea, though not the specific legal analogy, in its refusal to certify any but Evangelical Protestants as foster parents. ${ }^{56}$ The agency's mission is to place children in the most suitable homes, and for Miracle Hill, "most suitable" includes a necessary religious element. In its view, only the homes of co-religionists can provide for the spiritual and material welfare of children.

Prospective foster parents are not, however, prospective employees of the CPA. The CPA evaluates their suitability to serve in this state-created role, and ordinarily does so using secular criteria. If the CPA is also charged with monitoring the child's welfare after placement (conduct that is not included in this complaint about the licensing of Miracle Hill), the agency also evaluates the quality of care provided to the child. In doing so, the CPA stands in the place of the state, which bears ultimate responsibility for children in the foster care system. Seen in that light, prospective foster parents are properly understood as the program's secondary beneficiaries. Certification by the CPA opens for them the possibility of tangible and intangible benefits that come with providing foster care. ${ }^{57}$ If the CPA conditions certification on a confession of faith, it necessarily cuts some prospective foster parents off from those benefits. Because the state is fully aware of this religious condition yet continues to license and subsidize the work of Miracle Hill, the state should not be able to disclaim shared responsibility for the exclusion of non-adherents from participation as foster parents.

In its denial of the government's motion to dismiss, the court emphasizes the longstanding principle that government may not delegate civil authority to a religious entity. ${ }^{58}$

\footnotetext{
${ }^{55} 42$ USC $\$ 2000$ e-1(a). The co-religionist exemption is typically preserved when religious entities receive grants or contracts from the government to provide social welfare services. See, e.g., 28 CFR 38.2(f) (Department of Justice regulation on co-religionist preference by program grantees).

${ }^{56}$ State Defendants' 12(c) motion, 9-10 (“As part of its religious faith and practice, however, Miracle Hill believes that those it places in positions of spiritual responsibility-including foster parents-must share its religious beliefs, mission, and motivation").

${ }^{57}$ [Foster care benefits to families]

${ }^{58}$ Rogers, 466 F. Supp. 3d at 648-649.
} 
Delegation of discretionary governmental authority to a religious organization raises a core problem under the Establishment Clause. ${ }^{59}$ The Clause embodies a fundamental concern about the grant of police powers to religious authorities. Such delegation is a perfect example of the "entanglement" problem identified in Lemon. But because the decisions of religious authorities are intentionally placed beyond the scope of government control, ${ }^{60}$ those decisions are not publicly accountable. ${ }^{61}$ Although secular entities' decisions can be reviewed based on secular standards, a religious organization, and especially one empowered to make decisions based on their religious beliefs, is effectively insulated from public review. Thus, the government's delegation to Miracle Hill of the power to certify prospective foster parents based on their religious beliefs could represent an impermissible grant of public authority. ${ }^{62}$

Miracle Hill's exclusion of non-adherents is only one element of the government's vulnerability under the Establishment Clause. The CPA's policy aims specifically at the religious indoctrination of children placed in foster homes under its supervision. By concentrating on the religious beliefs and practices of prospective parents, Miracle Hill attempts to ensure that foster children will be immersed in Evangelical Protestantism. Compare a state's ordinary relationship with a CPA (even one that is faith-based). In that program, the scope of eligible foster homes will not be intentionally concentrated in a particular faith group and thus the state should bear no responsibility for the religious experience of a child placed in one of those homes. But when the state and federal authorities waived their rules to permit a contract with Miracle Hill, they were certainly aware of the CPA's policies and its relative size as a provider of foster care services. These government actors should not be able to disclaim responsibility for the result of the waivers - the religious indoctrination of children under Miracle Hill's supervision - even if the government did not intend to promote such indoctrination. ${ }^{63}$

\section{C. A compelling interest in prohibiting religious discrimination}

These arguments may assist the plaintiffs in Rogers, but the federal government is unlikely to raise the Establishment Clause as a defense to a Free Exercise claim by Miracle Hill.

\footnotetext{
${ }^{59}$ Larkin v. Grendel's Den, 459 U.S. 116, 123 (1982).

${ }^{60}$ That is, permission to discriminate based on religion effectively eliminates the state's power to control decisionmaking by that religious entity. The judgment of who is religiously suitable as an adoptive parent belongs solely to the religious entity - the government may not second-guess the religious entity's judgment about who is religiously suitable. See, e.g., Burgess v. Rock Creek Baptist Church, 734 F. Supp. 30, 33 (D. D. C. 1990) (Court may not evaluate a religious community's decision to expel a former member); see also Levitt v. Calvary Temple of Denver, 33 P.3d 1227, 1229-30 (Colo. App. 2001) (same).

${ }^{61}$ State v. Celmer, 80 N.J. 405, 416-418 (1979).

${ }^{62}$ This argument would not invalidate every grant of discretionary authority to religious organizations. Those that require decisions based on publicly accessible reasons would still be permitted. But those that permit religionbased discretionary judgments would be vulnerable to challenge.

${ }^{63}$ I recognize that an Establishment Clause claim focused on indoctrination of foster children faces the hurdle of standing doctrine that requires specific injury to the plaintiff. Hein v. Freedom from Religion Foundation, 551 U.S. 587 (2007). But religious discrimination in the selection of foster parents is the method by which the CPA guarantees specific religious experience for foster children. Because these children are not in a position to protect themselves, prospective foster parents should have proxy standing to bring an Establishment Clause challenge, designed to interrupt the CPA's intentional religious indoctrination of foster children.
} 
Perhaps for fear of limiting its own power to grant religious accommodations in other settings, the federal government has tended to avoid arguing that the Establishment Clause imposes a limit on such accommodations. ${ }^{64}$ The federal government might argue that the waiver provision invoked by the Trump HHS is unlike the exception central to the Fulton decision, but that argument is unlikely to be successful. Accordingly, to defeat Miracle Hill's Free Exercise claim, the government would need to show that the prohibition on religious discrimination by Miracle Hill is narrowly tailored to serve a compelling government interest. ${ }^{65}$

In Fulton, the Court offered only a perfunctory assessment of the government's interest in barring discrimination based on sexual orientation. It rejected the City's argument that CSS would limit the number of available foster homes by discriminating against same-sex couples. "If anything, including CSS in the program seems likely to increase, not reduce, the number of available foster parents." 66 The Court also said that the City's interest in restricting discrimination against same-sex couples is "weighty," but is not compelling because "[t]he creation of a system of exceptions under the contract undermines the City's contention that its non-discrimination policies can brook no departures." ${ }^{67}$

The federal government would have a much stronger position if it refused to permit Miracle Hill's religious discrimination in the certification of prospective foster parents. First, Fulton emphasized the wide range of alternative CPAs in Philadelphia that certify same-sex couples as foster parents. The City did not argue that same-sex couples lacked reasonable alternative opportunities, measured by accessibility and comparable quality. The record showed plenty of other CPAs, licensed and funded by the City, willing to serve same sex couples. ${ }^{68}$

On this question of alternative providers, the contrast between Fulton and Rogers is stark. In Rogers, plaintiffs contend that they had no reasonable alternatives to Miracle Hill, so denial by that CPA effectively barred them from participation in the state's foster care program. If proven, that feature alone should be sufficient to demonstrate that the federal government has a compelling interest in denying Miracle Hill's claim for a free exercise accommodation. The limited availability of other CPAs not only excludes non-Evangelical Protestants but

\footnotetext{
${ }^{64}$ See, e.g., Burwell v. Hobby Lobby Stores, 573 U.S. 682 (2014) (amici urged the Court to consider Establishment Clause violation in an accommodation that would cut off women employees and dependents from access to insurance coverage of contraceptives. The federal government did not trace concerns about third-party burdens to the Court's Establishment Clause precedents. It framed those concerns solely in terms of the "compelling interest" standard under RFRA).

${ }^{65}$ Note here the difference between "narrowly tailored" (Fulton, 141 S. Ct. at 1890, 1892, 1896 (Alito, J., concurring in the judgement) and "least restrictive means" (Hobby Lobby, 573 U.S. at 737-738). Narrow tailoring has not required the same (perhaps impossibly strict) requirement that the government have explored and exhausted all possible avenues for granting an accommodation. For example, the contraceptive mandate blocked in Hobby Lobby was narrowly tailored to the government's ends, but - according to the Court - it did not represent the means least restrictive of plaintiffs' religious liberty.

${ }^{66}$ Fulton, 141 S. Ct. 1868, 1882.

67 Id.

68 Id. at 1875 .
} 
undermines the government's interest in maximizing the number of foster homes. Including CSS may have increased the number of foster homes in Philadelphia but placing religious conditions on eligible foster parents in South Carolina is likely to restrict the number of foster care home placements. ${ }^{69}$ This is especially true when the state has significant need for additional foster homes, and the restriction is imposed by the state's largest CPA.

Second, Miracle Hill discriminates based on religion, which in its case includes discrimination based on sexual orientation. CSS discriminated based only on sexual orientation. I do not intend to make (and do not embrace) a normative argument that sexual orientation deserves less respect than religion under the Equal Protection Clause, but the federal government could distinguish the classifications based on the Court's Religion Clause and Equal Protection precedents. In Obergefell v. Hodges, ${ }^{70}$ Justice Kennedy's majority opinion concludes with a note of solicitude for religious communities that oppose same-sex marriage. "The First Amendment ensures that religious organizations and persons are given proper protection as they seek to teach the principles that are so fulfilling and so central to their lives and faiths, and to their own deep aspirations to continue the family structure they have long revered."71 Though the Court does not explain what "proper protection" means, the opinion certainly suggests that religious organizations possess a legitimate, countervailing interest, potentially of constitutional dimensions.

Moreover, the Court has not expressly declared sexual orientation a suspect classification under the Equal Protection Clause. ${ }^{72}$ Although Obergefell invokes the Equal Protection Clause, the Obergefell opinion intertwines that inquiry with the Due Process Clause's protection for dignitary interests and the fundamental right to marry. Obergefell thus does not neatly support an Equal Protection claim resting on sexual orientation alone. ${ }^{73}$

In sharp contrast, government supported discrimination based on religion is barred by both Religion Clauses as well as the Equal Protection Clause. ${ }^{74}$ The federal government would have at least two compelling interests in prohibiting religion-based discrimination by CPAs. One, prospective foster parents deserve equal treatment, without regard to their religious commitments, in access to the foster care program. Denial of that access stigmatizes non-

\footnotetext{
69 The state's willingness to tolerate this restriction would also carry significant weight in an Establishment Clause claim against the state. If Miracle Hill's policy does suppress the number of eligible foster parents, the state would be responsible for preferring the interests of the religious provider over the needs of program beneficiaries.

70576 U.S. 644 (2015).

${ }^{71} \mathrm{Id}$. at $679-680$.

72 It has passed up multiple opportunities to do so. Obergefell, 576 U.S. 644 (2015); U.S. v. Windsor, 570 US 744 (2013); Lawrence v. Texas, 539 US 558 (2003); Romer v. Evans, 517 US 620 (1996).

${ }^{73}$ See Obergefell, 576 US at 672-676.

${ }^{74}$ See, e.g., Kiryas Joel, 512 US 687, 702-704 (1994) (Establishment Clause); Lukumi, 508 US 520, 531-540(1993)

(Free Exercise Clause); Larson v. Valente, 456 U.S. 228, 253-255 (1982) (equal protection clause and religious clauses). The exception to this rule relates solely to matters internal to the religious community. See infra note (employment discrimination) and accompanying text. The provision of foster care services cannot be considered an "internal" matter because it requires delegation of the state's authority with respect to the welfare of children in the care of the state.
} 
adherents based on a characteristic that should be wholly irrelevant to a secular government. ${ }^{75}$ Two, the state's permission for Miracle Hill to discriminate in favor of co-religionists unquestionably favors that faith group. ${ }^{76}$ The federal government has a constitutionally mandated interest in its own religious neutrality, and favoritism for Miracle Hill undermines that interest. Given those interests, the federal government's decision to deny a waiver to Miracle Hill should be deemed "narrowly tailored." If, however, the court required the government to show that it used the least restrictive means of achieving its interest in promoting religious equality, the government might be ordered to ensure reasonable alternatives for prospective foster parents rejected by Miracle Hill - even if doing so required the government to absorb the cost. Although the Court suggested such an alternative in Hobby Lobby, ${ }^{77}$ it has never made such a suggestion in a case arising under the Free Exercise Clause. ${ }^{78}$ Such an order would substantially expand the scope and cost of religious exemptions required under any regime.

If HHS does withdraw the waiver for Miracle Hill, and the CPA files a Free Exercise claim against the federal government based on that action, the federal government has ample grounds for distinguishing Fulton, and protecting against the spread of co-religionist preferences across the panoply of government-funded social welfare programs. If Fulton were read to support Miracle Hill in this context, the Free Exercise Clause would have obliterated all the competing constitutional concerns raised in the Rogers litigation. It is impossible to believe that the Fulton majority, which rejected the most strenuous Free Exercise arguments raised in that case, was elevating Free Exercise norms to this unacceptable degree.

\footnotetext{
${ }^{75}$ See, e.g., U.S. Const. Art. IV $\S 3$ (prohibition on religious tests for federal officeholders; the holder's religion is a constitutionally irrelevant); Torcaso v. Watkins, 367 US 488, 496 (1961) (prohibition on religious test oaths for federal offices extended to state offices under the Free Exercise Clause)

${ }^{76}$ Although the Establishment Clause would be an obvious basis for resisting that favoritism, the federal government could instead rely on the equal protection component of the Due Process Clause, as developed in Bolling v. Sharpe. 347 US 497 (1954) (Fifth Amendment's Due Process Clause contains liberty interests otherwise protected by the Equal Protection Clause).

77 See, e.g., Hobby Lobby, 573 U.S. at 728-730.

78 In Sherbert v. Verner, 374 US 398 (1963), the Court reject the state's concern about fraud by noting that the state could readily screen against that problem. But the Court did not suggest that the state would need to set up an entirely different system of providing unemployment benefits.
} 